\title{
Performance of broilers fed digestible amino acids based diets obtained from cecectomized roosters and broilers
}

\author{
Alexandre Barbosa de Brito ${ }^{1}$, José Henrique Stringhini ${ }^{2,3}$, Suzany Aparecida Gomes Xavier ${ }^{1}$, \\ Marcos Barcellos Café ${ }^{2,3}$, Maria Auxiliadora Andrade ${ }^{4}$, Nadja Susana Mogyca Leandro 2,3 \\ 1 Poli-Nutri Alimentos, Osasco, SP, Brazil. \\ 2 Departamento de Produção Animal, Escola de Veterinária e Zootecnia, Universidade Federal de Goiás, Caixa Postal 131, 74001-070, \\ Goiânia, Goiás, Brazil. \\ 3 Pesquisador CNPq \\ ${ }^{4}$ Departamento de Medicina Veterinária, Escola de Veterinária e Zootecnia, Universidade Federal de Goiás, Caixa Postal 131, 74001-070, \\ Goiânia, Goiás, Brazil.
}

\begin{abstract}
This experiment was carried out to evaluate the performance of broilers fed ration formulated based on digestible amino acids obtained with cecectomized roosters and broilers at different ages. A total of 300 Ag Ross 508 broiler chicks aging one to 21 days was distributed into 30 experimental units of ten broilers each (five birds of each sex) in six batteries of galvanized steel. All diets were based on corn, soybean meal and full-fat corn germ meal, considering the values of diges tible amino acids obtained from 45-week-old roosters and broilers of 21 and 42 days of age. Two rearing phases were adopted, a pre-starter phase (one to seven days) and a starter phase (eight to 21 days). The following performance variables were evaluated: average weight, weight gain, feed intake, feed:gain relation and mortality. Birds were distributed according to a completely randomized design with three forms of determination of digestible amino acids content and ten repetitions of ten birds. The use of digestible amino acids based diets determined for broiler chicks at 21 days of age resulted in better performance of bro ilers in starter phase. The digestible amino acid values of each ingredient can vary according to the age of the birds during the determination procedure.
\end{abstract}

Key Words: different ages, digestibility, nutrition

\section{Introduction}

The use of the digestible amino acids' concept has become important in feed formulation and experiments for nutritional requirements' determination for broilers, in order to improve performance and carcass yield (Nascimento, 2004). However, some aspects must be adjusted for the correct use of this concept, such as the amino acid production by the cecal microflora (Farrell et al., 1999).

The microflora activity on protein digestion and amino acid digestibility still characterize conflicting issues. Therefore, to elucidate the consequences of this interaction, many methodologies have been developed to evaluate amino acid digestibility in ingredients, such as the use of SPF (specifc germ free) birds, the antibiotic inclusion in experimental rations, the ileal content obtained by cannulas, and the use of cecectomized birds (Lemme et al., 2004).

The Sibbald method has been widely used in assays on roosters, following Sibbald's recommendations (Sibbald, 1976). In these assays, birds' cecectomy is convenient to avoid cecal microflora effects on the digesta. Neverthless, cecectomized roosters excrete more endogenous amino acids compared with younger birds, even when they were fasted or received diets with glucose (Rutz, 2002). This fact can be explained by the physiological maturation status of the birds' gastrointestinal tract.

At hatch, the chick's gastrointestinal system is anatomically complete, but still immature in some digestion and absorption functions, when compared with adult birds. During the post-hatch period, the gastrointestinal tract undergoes many morphological changes, which result in an increased area for digestion and absorption (Maiorka et al., 2002). The most significant changes that occur are the increase of intestinal length, villi height and density and, consequently, in the number of caliciform cells, enterocytes and enteroendocrine cells (Nitsan et al., 1991).

The most pronounced increase in villus height in the duodenum of broilers starts in ovo, approximately on the $17^{\text {th }}$ day of the hatching period. However, the chick is only physiologically mature at seven days after hatching. In jejunum and ileum, it continues until the $20^{\text {th }}$ day of age (Uni et al., 1996). Thus, it is possible to imply that the 
determination of the nutritional content at ages close to the age of the birds leads to diets precisely formulated, which results in better performance.

Therefore, this experiment was accomplished to evaluate the performance of broilers fed diets formulated with digestible amino acids obtained from cecectomized broilers and roosters at different ages.

\section{Material and Methods}

This study was carried out in the experimental facilities of the Escola de Veterinária e Zootecnia of the Universidade Federal de Goias (EVZ/UFG) with three hundred Ag Ross chicks reared until 21 days of age and allotted in 30 experimental units. Birds were distributed in six galvanized steel batteries, with five floors measuring $0.80 \times 1.00 \times 0.40 \mathrm{~m}$ in a $24 \times 6.65 \times 2.6 \mathrm{~m}$ facility. In each battery floor unit, ten chicks (five of each sex) received feed and water in linear feeders and drinkers; 60 -W lamps were used for heating birds until 14 days of age. The lighting program consisted of 23 hours plus one hour of darkness to supply 22 lumens $/ \mathrm{m}^{2}$. Plastic curtains were used for environmental control.

Treatments consisted of three different forms of digestible amino acid determination in two phases: prestarter, from one to seven days of age, and starter, from eight to 21 days of age. All diets were formulated based on corn, soybean meal and full-fat corn germ meal, considering the digestible amino acid values obtained from 45-weekold cecectomized roosters and broilers at 21 and 42 weeks of age (Tables 1 and 2).

The bromatological composition of the ingredients was obtained (Table 3) and both the soybean meal and the full-fat corn germ meal used in the experiments had been produced two months before at most.

The experimental diets for broilers were offered from one to 21 days. Feeds and birds were weighed on the first, $7^{\text {th }}$ and $21^{\text {st }}$ days of age for determination of performance variables such as live weight, weight gain, feed intake and mortality rate. For statistical analysis, values were transformed into arc-sen.

Birds were allotted in a completely radomized design with three treatments as the determination forms of digestible amino acids of the feed used, and ten replicates of ten birds each, in a total of 300 chicks.

The statistical analysis was performed using SAEG (UFV, 2000) and Tukey test was used for mean comparison at $5 \%$ probability.
Table 1 - Composition of the experimental pre-starter diets (1 to 7 days of age)

\begin{tabular}{|c|c|c|c|}
\hline Ingredient & $\begin{array}{l}45 \text { week- } \\
\text { old } \\
\text { roosters }\end{array}$ & $\begin{array}{c}21 \text { day- } \\
\text { old } \\
\text { broilers }\end{array}$ & $\begin{array}{l}42 \text { day } \\
\text { old } \\
\text { broilers }\end{array}$ \\
\hline Corn, \% & 49.68 & 48.71 & 50.67 \\
\hline Full-fat corn germ meal, \% & 6.00 & 6.00 & 6.00 \\
\hline Soybean meal, \% & 38.18 & 39.24 & 37.29 \\
\hline Limestone, \% & 1.01 & 1.01 & 1.01 \\
\hline Dicalcium phosphate, \% & 1.86 & 1.66 & 1.76 \\
\hline Soybean meal, \% & 2.27 & 2.36 & 2.28 \\
\hline Common salt, \% & 0.46 & 0.46 & 0.46 \\
\hline Vitamin and mineral supplement ${ }^{1}, \%$ & 0.40 & 0.40 & 0.40 \\
\hline DL-methionine, \% & 0.15 & 0.17 & 0.14 \\
\hline Metabolizable energy, $\mathrm{kcal} / \mathrm{kg}$ & 2,950 & 2,950 & 2,950 \\
\hline otein, \% & 21.92 & 21.92 & 21.92 \\
\hline Calc & 0.99 & 0.99 & 0.99 \\
\hline le phosphorus, \% & 0.47 & 0.47 & 0.47 \\
\hline Sodiu & 0.22 & 0.22 & 0.22 \\
\hline Digestible lysine ${ }^{2}, \%$ & 1.24 & 1.23 & 1.26 \\
\hline Digestible methionine + cystine $^{2}$, \% & 0.83 & 0.83 & 0.83 \\
\hline Digestible methionine $^{2}$, \% & 0.48 & 0.50 & 0.48 \\
\hline Digestible threonine ${ }^{2}, \%$ & 0.84 & 0.80 & 0.84 \\
\hline Digestible tryptophan ${ }^{2}$, \% & 0.26 & 0.26 & 0.26 \\
\hline Digestible arginine ${ }^{2}, \%$ & 1.50 & 1.49 & 1.51 \\
\hline eometric diameter, $\mu \mathrm{m}$ & 890 & 893 & 890 \\
\hline Mongin number, $\mathrm{mEq} / \mathrm{kg}$ & 234.39 & 234.02 & 234.8 \\
\hline
\end{tabular}

${ }^{1}$ Mineral and vitamin supplement (amount of nutrients per kilogram of product): folic acid - $200 \mathrm{mg}$; panthotenic acid - 3,120 mg; antioxidant - 2.50\%; copper - 2,000 mg; choline - 78,300 mg; iron - 11,250 mg; iodine - $187.50 \mathrm{mg}$; manganese - 18,750 mg; niacin - 8,400 mg; biotin - $10 \mathrm{mg}$, coccidiostat - $2.50 \%$; growth promoter - $2 \%$; gentian violet - $0.375 \%$; riboflavin - 1,425 mg; selenium - $45 \mathrm{mg}$; vitamin A 1,680,000 UI; vitamin B1 - 436.50 mg; vitamin B2 - 1,200 mg; vitamin B6 - $624 \mathrm{mg}$ vitamin B12 - 2,400 mcg; vitamin K3 - 360 mg, vitamin D3 - 400,000 IU; vitamin E - 3,500 mg; zinc - 15,500 mg.

2 Nutritional composition proposed by Rostagno et al. (2000).

Table 2 - Composition of the experimental starter diets (1 to 7 days of age)

\begin{tabular}{|c|c|c|c|}
\hline Ingredient & $\begin{array}{l}45 \text { weeks } \\
\text { old } \\
\text { roosters }\end{array}$ & $\begin{array}{l}21 \text { days } \\
\text { old } \\
\text { broilers }\end{array}$ & $\begin{array}{c}42 \text { days } \\
\text { old } \\
\text { broilers }\end{array}$ \\
\hline orn, \% & 39.72 & 37.74 & 41.71 \\
\hline ull-fat corn germ meal, \% & 20.00 & 20.00 & 20.00 \\
\hline oybean meal, \% & 34.34 & 36.19 & 32.33 \\
\hline imestone, \% & 1.03 & 1.04 & 1.02 \\
\hline Dicalcium phosphate, \% & 1.68 & 1.68 & 1.68 \\
\hline Soybean meal, \% & 2.28 & 2.36 & 2.30 \\
\hline Common salt, \% & 0.44 & 0.44 & 0.44 \\
\hline Vitamin and mineral supplement ${ }^{1}$, \% & $\% \quad 0.40$ & 0.40 & 0.40 \\
\hline DL-methionine, \% & 0.13 & 0.15 & 0.12 \\
\hline Metabolizable energy, kcal/kg & 3,000 & 3,000 & 3,000 \\
\hline Crude protein, \% & 20.88 & 20.88 & 20.88 \\
\hline Calcium, \% & 0.94 & 0.94 & 0.94 \\
\hline Available phosphorus, \% & 0.44 & 0.44 & 0.44 \\
\hline Sodiu & 0.22 & 0.22 & 0.22 \\
\hline Digestible lysine ${ }^{2}$, \% & 1.18 & 1.17 & 1.20 \\
\hline Digestible methionine + cystine ${ }^{2}$, \% & 0.79 & 0.79 & 0.79 \\
\hline Digestible methionine ${ }^{2}, \%$ & 0.45 & 0.47 & 0.45 \\
\hline Digestible threonine $^{2}, \%$ & 0.80 & 0.76 & 0.80 \\
\hline Digestible tryptophan ${ }^{2}$, \% & 0.24 & 0.24 & 0.24 \\
\hline Digestible arginine $^{2}, \%$ & 1.46 & 1.44 & 1.46 \\
\hline Medium geometrical diameter, $\mu \mathrm{m}$ & 850 & 845 & 847 \\
\hline Mongin number, $\mathrm{mEq} / \mathrm{kg}$ & 230.43 & 230.15 & 230.22 \\
\hline \multicolumn{4}{|c|}{$\begin{array}{l}{ }^{1} \text { Mineral and vitamin supplement (amount of nutrients per kilogram of product): } \\
\text { folic acid - } 200 \mathrm{mg} \text {; panthotenic acid - 3,120 mg; antioxidant - } 2.50 \% \text {; copper - } \\
\text { 2,000 mg; choline - 78,300 mg; iron - } 11,250 \mathrm{mg} \text {; iodine - } 187.50 \mathrm{mg} \text {; manganese - } \\
18,750 \mathrm{mg} \text {; niacin - 8,400 mg; biotin - } 10 \mathrm{mg} \text {, coccidiostat - } 2.50 \% \text {; growth } \\
\text { promoter - } 2 \% \text {; gentian violet - } 0.375 \% \text {; riboflavin - } 1,425 \mathrm{mg} \text {; selenium - } 45 \mathrm{mg} \text {; } \\
\text { vitamin A - 1,680,000 UI; vitamin B1 - } 436.50 \mathrm{mg} \text {; vitamin B2 - } 1,200 \mathrm{mg} \text {; vitamin } \\
\text { B6 - } 624 \mathrm{mg} \text {; vitamin B12 - 2,400 mg; vitamin K3 - } 360 \mathrm{mg} \text {, vitamin D3 - 400,000 IU; } \\
\text { vitamin E - 3,500mg; zinc - 15,500 mg. } \\
2 \text { Nutritional composition proposed by Rostagno et al. (2000). }\end{array}$} \\
\hline
\end{tabular}


Table 3 - Nutritional composition of corn, soybean meal and full-fat corn germ meal used in the diet formulation

\begin{tabular}{|c|c|c|c|}
\hline Nutrients & Corn $^{1}$ & Soybean meal ${ }^{1}$ & Full-fat corn soybean meal ${ }^{2}$ \\
\hline Metabolizable energy, kcal/kg & 3.371 & 2.266 & 3.350 \\
\hline Crude protein, \% & 8.57 & 45.54 & 10.88 \\
\hline Calcium, \% & 0.03 & 0.32 & 0.02 \\
\hline Available phosphorus, \% & 0.08 & 0.19 & 0.07 \\
\hline \multirow[t]{2}{*}{ Sodium, \% } & 0.03 & 0.07 & 0.03 \\
\hline & \multicolumn{2}{|c|}{ Digestible amino acid content obtained from 45 -week old roosters 3} & roosters ${ }^{3}$ \\
\hline Digestible lysine, \% & 0.268 & 2.827 & 0.538 \\
\hline Digestible methionine + cystine, \% & 0.327 & 1.304 & 0.427 \\
\hline Digestible methionine, \% & 0.152 & 0.644 & 0.204 \\
\hline Digestible threonine, \% & 0.286 & 1.748 & 0.411 \\
\hline \multirow[t]{2}{*}{ Digestible arginine, \% } & 0.449 & 3.225 & 0.838 \\
\hline & \multicolumn{2}{|c|}{ Digestible amino acid content obtained from 21-day old broilers ${ }^{3}$} & broilers ${ }^{3}$ \\
\hline Digestible lysine, \% & \multicolumn{2}{|c|}{ Digestible amino acid content obtained from 42-day old broilers ${ }^{3}$} & broilers $^{3}$ \\
\hline Digestible lysine, \% & 0.280 & 2.83 & 0.549 \\
\hline Digestible methionine + cystine, \% & 0.331 & 1.313 & 0.437 \\
\hline Digestible methionine, \% & 0.152 & 0.646 & 0.206 \\
\hline Digestible threonine, \% & 0.288 & 1.750 & 0.424 \\
\hline Digestible arginine, \% & 0.454 & 3.230 & 0.850 \\
\hline
\end{tabular}

${ }^{1}$ Nutritional composition proposed by Rostagno et al. (2000).

2 Nutritional composition proposed by Brito et al. (2005).

${ }^{3}$ Nutritional composition proposed by Brito et al. (2011).

\section{Results and Discussion}

Temperature and relative humidity in the facilities (Table 4) were measured and maintained appropriate according to recommendations for handling the birds used in the experiment.

The performance evaluation of broilers at 21 days of age fed digestible amino acid based diets determined from cecectomized broilers at 7 days of age showed significantly better results $(\mathrm{P}<0.05)$ for mean weight, weight gain and feed:gain relation, especially for the starter period (1 to 21 days of age) (Table 5). It is possible to estimate that the mean weight at 7 days of age was improved about $1 \%$ for broilers fed diets formulated based on digestible amino acids and determined from cecectomized broilers at 21 days of age compared to the ones fed diets formulated based on digestible amino acid determined from cecectomized 45-week old roosters. In these birds, feed intake decreased about 3\% and the feed:gain relation was $2.7 \%$ better (Table 5).

Broilers responded distinctly to the experimental diets and, according to Ali \& Leeson (1995), the most precise formulation and performance prediction are important to the modern poultry production. These authors emphasize that small variations on amino acid levels can produce a great difference in the earnings from the activity.

Lemme et al. (2004) pointed out that the great concern of the poultry industry was the use of digestibility values generated by the metabolic assays with roosters because their gastrointestinal tracts are physiologically different from those of growing birds.

Some data from experiments on aging effects and amino acid use prove an increased digestibility improvement as the bird ages. Doeschate et al. (1993) evaluated many factors that influence amino acid digestibility in broilers using the cecal cannula methodology and pointed to age, sex and genotype as main factors because older broilers excrete lower amino acid levels than growing broilers. Because of this, amino acid levels determined with roosters are higher.

Perttilä et al. (2001) evaluated the amount of amino acids in barley by the ileal collection method with growing broilers and roosters and observed that the ileal digestibility is lower in 21 day-old broilers than in 40 week-old roosters.

As similar to the data obtained by Lemme et al. (2004), apparent ileal digestibility data for roosters were really different from growing broilers, and it can result in great differences in feed formulation.

Although the obtained data is non-significant $(\mathrm{P}>0.05)$ (Table 5), the mortality rate increased in broilers that consumed diets based on amino acid digestibility obtained from broilers; however, no plausible explanation for this finding has been found. This rate refers to one bird that died on the $15^{\text {th }}$ day of experiment, diagnosed as sudden death syndrome or cardiorespiratory failure because of the position in which the animal was found and the congestion observed in the thoracic veins. This can be 
Table 4 - Mean temperature and air humidity observed during the experimental period

\begin{tabular}{|c|c|c|c|c|c|c|}
\hline \multirow[t]{2}{*}{ Weeks } & \multicolumn{3}{|c|}{ Temperature $\left({ }^{\circ} \mathrm{C}\right)$} & \multicolumn{3}{|c|}{ Relative humidity (\%) } \\
\hline & Maximum & Minimum & Mean & Maximum & Minimum & Mean \\
\hline 1 & 33.80 & 30.20 & 32.00 & 86.50 & 65.30 & 75.90 \\
\hline 3 & 29.50 & 25.30 & 27.40 & 83.20 & 46.20 & 64.70 \\
\hline Mean & 31.67 & 28.40 & 30.03 & 85.37 & 55.57 & 70.47 \\
\hline
\end{tabular}

Table 5 - Performance of broilers fed diets based on digestible amino acid content obtained from cecectomized roosters and broilers

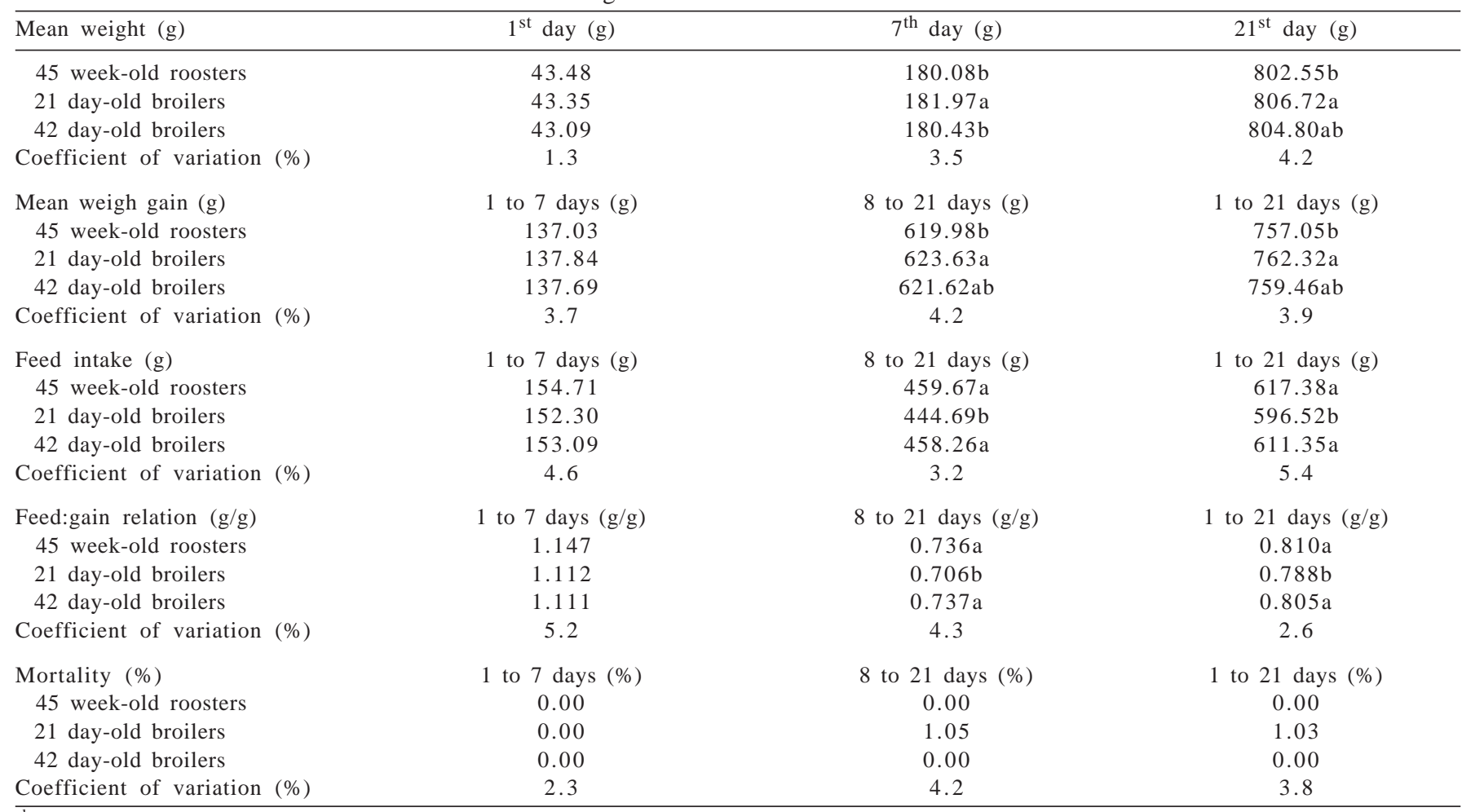

ab Different letters in the same column indicate difference $(\mathrm{P}<0.05)$ by Tukey test.

due to the improvement of broiler's performance, which increases the incidence of lung hypertension (Odum, 1993). It is well-known that the growing rate is an important factor that overloads the demand of oxygen tissue, which leads to the cardiorespiratory system failure, increasing mortality rates (Julian, 2005).

The use of digestible amino acid values determined in ages closer to the birds' growing phase might contribute positively to improve performance due to more accurate nutritional results.

\section{Conclusions}

For broilers at the starter phase, the formulation of digestible amino acid ration determined from 21-day-old broilers is adequate and can increase performance at a rate of 2 to $3 \%$. For growing and final phases, nutritionists can formulate diets using digestible amino acid data obtained from roosters or 42-day-old broilers.

\section{Acknowledgements}

To CNPq, GEM Alimentos, Evonik-Degussa and CNPq, for the financial support for the project. To Karla Avanço, for helping us translate this article.

\section{References}

ALI, M.A.; LEESON, S. The nutritive value of some indigenous Asian poultry feed ingredients. Animal Feed Science and Technology, v.55, n.2, p.227-237, 1995.

BRITO, A.B.; STRINGHINI, J.H.; CRUZ, C.P. et al. Avaliação nutricional do gérmen integral de milho para aves. Ciência Animal Brasileira, v.6, n.1, p.19-26, 2005.

BRITO, A.B.; STRINGHINI, J.H.; XAVIER, S.A.G. et al. Digestibilidade dos aminoácidos do milho, farelo de soja e gérmen integral de milho em galos e frangos de corte cecectomizados. Revista Brasileira de Zootecnia, v.40, n.10, p.2147-2151, 2011.

DOESCHATE, R.A.H.M.; SCHEELE, C.W.; SCHREURS, V.V.A.M. et al. Digestibility studies in broilers chicks: Influence of genotype, age,sex and method of determination. British Poultry Science, v.34, n.1, p.131-146, 1993.

FARRELL, D.J.; MANNION, P.F.; PEREZ-MALDONADO, R.A. A comparison of total and digestible amino acids in diets for 
broilers and layers. Animal Feed Science and Technology, v.82, n.1, p.131-142, 1999.

JULIAN, R.J. Production and growth related disorders and other metabolic diseases of poultry - A Review. The Veterinary Journal, n.169, p.350-369, 2005

LEMME, A.; RAVINDRAN, V.; BRYDEN, W.L. Ileal digestibility of amino acids in feed ingredients for broilers. World's Poultry Science Journal, v.60, n.4, p.423-438, 2004.

MAIORKA, A.; BOLELI, I.C.; MACARI, M. Desenvolvimento e reparo da mucosa intestinal. In: MACARI, M., FURLAN, R.L., GONZALES, E. (Eds.) Fisiologia aviária aplicada a frangos de corte. 2.ed. Jaboticabal: FUNEP/UNESP, 2002. p.113-124.

NASCIMENTO, A. Exigência de aminoácidos para frangos de corte. In: CONFERÊNCIA APINCO 2004 DE CIÊNCIA E TECNOLOGIA AVÍCOLAS, 2004, Santos. Anais... Campinas: FACTA, 2004. p.103-116.

NITSAN, Z.; DUNNINGTON, E.A.; SIEGEL, P.B. Organ growth and digestive enzymes levels to fifteen days of age in lines of chickens differing in body weight. Poultry Science, v.70, n.12, p.2040-2048, 1991.
ODUM, T.W. Ascites syndrome: overview and update. Poultry Digest, n.52, p.14-22, 1993.

PERTILLÄ, S.; VALAJA, J.; PARTANEN, K. et al. Effects of preservation method and beta-glucanase supplementation on ileal amino acid digestibility and feeding value of barley for poultry. British Poultry Science, v.42, n.2, p.218-229, 2001.

ROSTAGNO, H.S.; ALBINO, L.F.T.; DONZELE, J.L. et al. Tabelas brasileiras para aves e suínos: composição de alimentos e exigências nutricionais. 3.ed. Viçosa, MG: UFV, 2000. 61p.

RUTZ, F. Proteínas: digestão e absorção. In: MACARI, M.; FURLAN, R.L.; GONZALES, E. Fisiologia aviária aplicada a frangos de corte. 2.ed. Jaboticabal: FUNEP/UNESP, 2002. cap.10, p.135-142.

SIBBALD, I.R. A bioassay for true metabolizable energy in feedingstuffs. Poultry Science, v.55, n.2, p.303-308, 1976.

UNIVERSIDADE FEDERAL DE VIÇOSA - UFV. SAEG - Sistema de análises estatísticas e genéticas. Versão 7.1. Viçosa, MG: FUNARBE, 2000. 150p. [Manual do usuário].

UNI, Z.; NOY, Y.; SKLAN, D. Development of the small intestine in heavy and light strain chicks before and after hatching. British Poultry Science, v.36, n.1, p.63-71, 1996. 